\title{
Explaining Proofs of Extensibility of Meaning in interpretation of the Holy Koran
}

\author{
Tahmineh Parsaei (Ph.D) (Corresponding author) \\ Department: of Theology and Philosophy Science and Research Branch, Islamic Azad \\ University ' Tehran - Iran \\ Tel: +989124680883 E-mail:ptahminaa@yahoo.com
}

\author{
Accepted: May 21, 2013 Published: June 26, 2013 \\ Doi:10.5296/ijld.v3i3.3919 URL: http://dx.doi.org/10.5296/ijld.v3i3.3919
}

\begin{abstract}
Extensibility of the meaning of words means expanding the range of instances of words so that the new meaning is in the line with the original state of the word and connected to its original meaning. Interpreters of the Quran have practiced this technique in their interpretations of the Quran in the form of batn [latent meanings of the Quran that are revealed], interpretation, and jary [the conclusively of the Quran's verses, meaning that the scope of the meaning of verses is not limited to the determinate instances at the time of revelation] and have presented various proofs for the validity of this technique. This technique allows benefiting from the text and meaning of the Quran to the highest possible capacity and prevents improper interpretations. In fact, this technique unfolds the miraculous verbal aspect of the Quran. This paper tries to discuss and expound the most important reasons provided by proponents of this technique that have been extracted from creditable interpretation books. The reasons include: attending characteristics of the speaker (God Almighty), development of man's perceptive faculty in the course of history, different talent and capacity of human beings in each epoch and referring to traditions of descendants of the Prophet of Islam who have applied this technique in interpretation of Quran's verses.
\end{abstract}

Keywords: Meaning extension, words of the Quran, interpretation technique, verbalizer of the Quran

\section{Introduction}

Undoubtedly our understanding of the Quran is achieved through words, and an interpretation of the Quran has no choice but to base itself on unfolding the meaning of the same words and their purport. Hence, the Quran may be understood and inferred by those people who are familiar with the Quran terminology and base their deductions on the literal meaning of the words and their relation. However, this question persist which meaning is the basis of this attempt; the meaning generally recognized at the time of revelation and its instances were shown in Arabic poetry and prose, or does this meaning cover a broader range and we should attribute more meanings to the words along with the original meaning?

Interpreters of the Quran have different approaches in deducting the meaning of the Quran's verses. Some observe that the meaning of words at the time of revelation must be taken as the basis of apprehension of the Quran. Therefore, the meaning of verses is the same conventional meaning grasped by Arabs upon revelation of the Quran and broadening the meaning of the 
verses is not advisable. Perhaps, Akhbaris, Zahiris and Salafis may be mentioned as proponents of this approach.

The second group favors this idea that the Quran should be comprehensible by its addressees, and the conventional meaning of the time of revelation was only one level of the meaning of verses while the verses have other meanings that may be conceived by people in other epochs. They hold, therefore, that comprehension of the Quran is not limited to the people of the same era but as society and human knowledge develops new and fresh interpretations of Quran verses become possible. Of course, they add this attempt must be based on certain standards and criteria in order to prevent chaos and arbitrary interpretations.

The third group favors extensibility of the meaning of words without any limitations and constraints and argues that words by themselves are not the final end of the Lord's speech but God's intent should be sought in the essence of the Quran. The exegeses presented by various schools such as Akhvan Al-Safa (Brethren of Purity), Batiniyya, sufis, or contemporary social and scientific interpretation, like those by Forqan Group or Seyed Ahmad Khan, may be classified as proponent of this approach.

(see Kamali Dezfuli, 1985, pp. 453)

There is no specific criterion to classify opponents and proponents of meaning extensibility because various factors encourage the interpreters to favor or refute it, and this may be attributed to their affiliation to various schools that shape their attitude towards meaning extensibility.

\section{History of Discussion}

Ghazali (505), Fakhr Razi (606), Ibn Rushd of Andalus (595) and Ibn Arabi (623) are the scholars who may be classified as proponents of meaning extensibility. Each of them favors this technique for certain reasons; the first approved it because of his interest in ethical interpretations, the second because of his engagement in theological debates, the third for liking philosophical approaches and finally the fourth, Muhioddin Arabi because of interest in mystical ideas tended to meaning extensibility. On the other hand, figures such as Ibn Al-arabi (543) and Shatibi (790) opposed extending meaning of Qoran beyond what perceived by Sahabah [companions of the prophet of Islam]. In the contemporary era, other researchers have discussed this matter as topics such as commonness in meaning, batn, exegesis, and have shown agreement with meaning extensibility in order to pave the way for combining religion and science, and to meet current needs and argue against the doubts raised by opponents in scientific, legal and social areas, including human rights, women's rights, justice, liberties etc. (Ayazi, 2007, pp. 622)

The books and resources referred to in this research:

- Contemporary Shiite interpretations of the Quran, especially Tafsir Al-mizan by Allameh Mohammadhossein Tatabai

- Inclusivity of Meaning in Interpretation of the Quran, by Seyed Mohammadali Ayazi

- Islam and Current Necessities and The Seal of Prophecy, by Morteza Motahari

- Polysemy in the Holy Quran by Seyed Mahmoud Tayebhosseini

- Shadows and Meaning Layers, by Mohammad As'adi

Arguments of proponents of meaning extensibility can be summarized as follows:

First reason: Speaker of the Holy Quran is God Almighty

Contemplating blessed verses of the Holy Quran demonstrate some basic facts; first, verses of Quran were revealed by God to the Prophet through the trustful angel of God, and the Prophet's 
task was only to read out, publicize and clarify the verses for the people (Al-Asra, verse 106). Secondly, the Quran itself clearly states that verses of the Quran are verbatim words of the Lord (Kahf, verse 27, Al-Tawba, verse 6). Furthermore, intrinsic characteristics of the Quran's language and its high eloquence and consistency reject the claim that it may be the product of non-divine source (Al-Nisa, verse 82). Additionally, a historical view of the personality of the Prophet of Islam and his life before being appointed as the messenger of God it is not reasonable to call the Quran words of His Highness (As'adi, 2007, pp. 24).

When it is ensured that the Holy Quran is the God's words this question is posed whether the uniqueness of the Speaker, God Almighty, makes the God's words distinguished from the man's speech, and whether this advantage may allow extending the scope of Quran's words.

In this connection, a contemporary scholar favors this idea that being the divine words distinguishes the Quran from the man's words and improves its semantic capacities. He says when the speaker is God who feels no limitation in knowledge or will he is able to convey various meanings through a verse (Javadi Amoli, 2009, pp. 120). A Sunni interpreter of the Quran refers to the verse "Say, [O Muhammad], "It has been revealed by He who knows [every] secret within the heavens and the earth. Indeed, He is ever Forgiving and Merciful." and says: "This book is sent by the Creator who knows secrets of the heavens and earth, and if He speaks to the extent of the knowledge of the people of each era it does not mean that God's knowledge is limited to the man's understanding. The meaning of the Quran is in accordance with the truth of existence though the words symbols of the truth and reveals only some aspects of it, and scientific is revealed to the extent of understanding of the past generation or coming generation.” (Ibn Ashur, 1884, vol. 2, p. 44)

Other interpreters have come to the same conclusion with different words. They say each word in a verse is assign for all aspects and probabilities that may be supposed in the verse and any meaning that may be imagined for the words because the Speaker is conscious of all the aspects and well knows his slaves are different in perceiving and understanding his speech. Furthermore, God does not require men to accept a meaning other than they perceive." (Sajjadi, 2000, pp. 57)

It seems the advantages attributed by the Quran interpreters to the God's wording pave the way for accepting the extensibility of the Quran's meaning. The advantages may be listed as follows:

a) God Almighty who knows the existence and properties of objects encircles the universe. This divine knowledge and governance is also present in words of language and its phonetics and semantics, hence when God issues a set of words he is able to select words and phrases in a polysemic manner while all the possible meanings do not fall outside of his purpose. Of course, language suffers from certain limitations, and God Almighty must talk to human beings in a language perceivable by them. The constraints cause the use of words to be limited.

b) Another characteristic of God Almighty is his knowledge of all events in the past and the future. God is aware of all needs of man at the time of revelation, and after that knows what is good and what is bad for man. Hence, with respect to the former characteristic - God's perfect knowledge of words and his infinite ability to arrange words in the best literary styles - God can use the capacity of words and linguistic forms to the maximum and present his purposes with smallest number of words and briefest phrases, and in doing this God attends all goodness and badness and organizes phrases in a manner that allows the highest use of the words and phrases (As'adi, ibid) If we take into account these characteristics for the composer of the sacred words it will be reasonable to accept polysemy. Furthermore, we can assert if God Almighty endows this ability to man he can take advantage of this feature and employ polysemy and words with several meanings in order to convey his purpose. 


\section{Analysis and Discussion}

According to this argument, characteristics of the speaker influence his speech. This is a fact affirmed by many scholars who call this as the continuous verbal evidence. (Rajabi, 2009, p. 165)

It should be acknowledged only those characteristics of the speaker may be taken as an evidence that are easily and clearly discernible by listeners because according to principles of eloquence the speaker cannot put the evidence of his speech the facts that are unknown to the listeners because his speech based on that evidence cannot convey his purpose and listeners fail to grasp it.

Therefore, the characteristics and features of God Almighty that cannot be understood by the public or is too difficult to be understood by listeners of the Holy Quran cannot be classified as the evidences in the sacred verses. Only those characteristics of God that are obvious to listeners through intuition or by reason or according to explicit statements in the Quran and traditions may be considered as evidences of verses and can play a role in the formation and content of the verses. (Rajabi, 2008, p. 169)

Another matter is characteristics of the listeners and its effect on their understanding of the speech of the speaker. Though God Almighty is able to issue speeches bearing with various meanings but if recipients are unable to grasp those meanings but one or if the God's speech are received by them as ambiguous or vague words the God's purpose will fail though some interpreters refer to a number of verses of the Quran and narratives from holy saints (peace be upon them) and categorize recipients of the God's speech into three groups: first, the Prophet of Islam who, for his extraordinary spiritual and mental capacity, could receive various meanings from the very same text of the Quran. Apart from the Prophet of Islam there are two groups who are to receive the God's words: first the people of the same era, and the people of coming epoch and ages, as this verse of the Quran says "And this Qur'an hath been inspired in me, that I may warn therewith you and whomsoever it may reach." (Al-An'am, 19) According to this verse, the Quran has been sent to talk to the people contemporaneous to the Prophet in Mecca and Medina, as well as the subsequent generations. Therefore, verses of the Quran have parallel meanings that are gradually unfolded in the course of time (Tayeb Hosseini, 2009, pp. 84). This idea is also seen in the narratives quoted from Imams (peace be upon them). Imam Muhammad Baqer is quoted as saying: "the Quran and its verses are eternal and will never wane because if verses of the Quran were sent for a single nation they would vanished with the disappearance of that nation, while the Quran is valid for the present and future generation as it was for the people of the past." (Koleini, pp. 191)

\section{Second reason: The people of revelation era had different faculty of perception even among sahaba [companions, disciples, scribes and family of theIslamic prophet Muhammad]}

It is no doubt that Arabic-speaking people in the era of revelation, especially those who had lived in the Period of Ignorance spoke in the same language of the Quran, and the Quran was uttered in a way to be understood by ordinary people. Therefore, a way to probe into the applied meaning of the Quran's words is to contemplate on the meaning of its words in the Arabic language of the revelation era. (Balaghi, vol. 1, p. 32)

Furthermore, statements of sahaba about the meaning of Quran's words is a source that help interpreters of the Quran grasp the meaning the words when the Quran was revealed to the Prophet. Even if we doubt the role of sahaba's statements in understanding the God's true purpose of the words used in the Quran we cannot call in question the fact that sayings of 
Sahaba will lead us to the applied meaning of words in the time of revelation (Rajabi, 2008, p. 296).

It should be noted that some think the people in the time of revelation of the Quran could entirely understand the God's purpose of the words used in the Quran and did not have need for exegesis. Ibn Khaldun (1375, vol. 1, p. 348) favored this idea that since the Quran had revealed in Arabic and followed Arabic verbal style all Arab people perceived the meaning of the Quran's single words and their combination: "beware the Quran was revealed in Arabic and its style of eloquence. Therefore, they could grasp the meaning of its single words and their combination."

Contrary to this conclusion, the fact that the language of the Quran is Arabic does not ensure that all Arabs perceive the Quran correctly because Islam presented concepts and ideas that did not exist in pre-Islamic literature. In other words, the Quran's words and phrases, besides bearing detonation and applied meaning as found in Arabic have new religious concepts with themselves. These concepts cannot be extracted from Arabic language only but must be sought in the essence of religion and its promoter. The Prophet of Islam is the messenger of last divine religion and the founder of greatest change in intellectual fundamentals and social systems who postulated the most excellent theological thoughts, therefore it is not wise to think people cannot find out the essence of the Quran because of not being native Arabs.

Additionally, there are numerous narratives that shows cases when even Sahaba were not aware of the denotative meaning of verses at the time of revelation. As Adi ibn Hatem Taei (67 Hegira) is quoted as saying after that the verse "eat and drink until the white thread of dawn becomes distinct to you from the black thread" (Al-Baqara, 187) was revealed he said to the Prophet "oh Prophet! I put two white and black threads under my pillow and distinguish day and night by the threads, and Prophet explained that the meaning of the black thread is the darkness of night, and the white threat is the light of day." (Tabari, 1420, vol. 5, p. 211)

It is also worth noting that not all sahaba were identical in terms of knowledge and the faculty of interpretation of the Quran. This difference is well understood from this statement of sahaba themselves. It is said that Abubakr was questioned about the verse "And ever is Allah, over all things, a Keeper" (Al-Nisa, 85) and he replied: "Which heaven has overshadowed me and which earth embraces me? What should I say if I don't know about the God's book?". Furthermore, Anas is quoted that Umar that he was lecturing on the minbar and cited the verse "And fruit and grass" (Abasa, 31) and then he said "we know fruit, but what is meaning of grass?" and while was contemplating said "By God! This subject is too difficult" (Ibn Kasir, 1412, vol. 2, p. 80, and Sivati, 1365, pp. 317). At any rate, difference between people is natural , and therefore Sahaha of the Prophet of Islam were ranked differently in terms of knowledge due to their different intelligence and talent (Shatebi, 1415, vol. 2, p. 87). There are numerous narratives about different understanding of Sahaba that may be seen in exegesis and narrative books (see Tabari, 1420, p. 76, and Koleini, vol. 1, pp. 62).

We conclude that sahaba of the Prophet of Islam did not have equal knowledge of the Quran, and this difference resulted from their different talents and capacity, their interest in learning and as well the extent of their association with the Prophet. On the other hand, this difference may also be due to the different tools they employed in understanding the Quran. For instance, some of the companions of the Prophet had greater access to information through their familiarity with Arabic literature and poetry while some other were deprived of this ability and therefore some of them had a deeper understanding of the Quran's verses while the others developed a shallower understanding owing to the same different faculties. Though there were different understandings all them might bear some degree of truth. Now, this question is raised; what is the relation between sahaba's different understanding and the inclusivity and extensibility of the meaning of the Quran? We can furnish these answers: first, the all or nothing law does not work in the field of interpretation of the Quran. In other words it is not 
correct to say an interpreter knows everything or nothing of the subject to be studied but an interpretation is two-sided and the validity of an interpretation depends on individual characteristics of the interpreter and the tools he or she has access to. Therefore, an interpreter with certain abilities may achieve a certain degree of meaning while another may go further. Secondly, none of the Quran interpreters in the age of sahaba and afterward claimed to be a perfect interpreter of the Quran but they always referred to their understanding as a degree and level of in understanding the essence of the Quran. Thirdly, when it is discovered that the sahaba who lived in the same era had different understandings of the Quran how is it unwise to expect an improvement in the interpretation of the Quran in subsequent periods with accelerating development and growth of science and increasing expansion of man's consciousness and tools of survey regarding the fact that Quran is God's words and besides being a miracle contains numerous layers of meaning?

\section{Analysis and discussion}

Undoubtedly, to realize the historical and geographical conditions of the society where the Holy Quran was revealed is a key to the presentation of a correct and precise interpretation of the Quran. Honorable sahaba of the Prophet of Islam were in contact with these conditions directly and immediately but this is not the only requirement to grasp the meaning of the Quran's verses but there are other factors such as intellectual capacity, intelligence and the ability to analyze contribute considerably to exegesis of the Quran. Perhaps, for the same reason, Imam Sadiq (peace be upon him), in classifying verses of the Quran, says: "The Book of God Almighty is divided into four sections: explications, implications, anecdotes and truths. Explications are for common people, implications may be grasped by selected people, holy persons understand anecdotes, and truths are discernible only by Prophets of God." (Majlesi, 1403, vol. 75, p. 278)

These shows even sahaba were in various ranks in terms of understanding and inference from the Quran's verses. Surely, Ibn Abbas and Umar and Abubakr were not alike in their faculties, and Ibn Abbas was not comparable to Ali (peace be upon him) in this regard.

Evidently the Prophet himself was aware of different qualifications of his companions, and this difference was attributed to the depth of their faith knowledge of truth of existence and the Holy Quran, and perhaps these factors determined their relationship with the Ahl Al-Bayt of the Prophet.

Ali (peace be upon him) is quoted about Salman Farsi: "Salman acquired the first and last knowledge, he is a sea which never dries, he is one of us, the Ahl Al-Bayt of the Prophet."

The Holy Prophet (may God's peace be upon him) describes Salman with these words: "if Abuzar knew what Salman knew the latter anathemized the former." (Motahari, 1366, pp. 162) This hadith recounts essential difference and inequal capacities of sahib. With a little contemplation we can distinguish different qualities among companions of Shiite imams where Imam Ali (peace be upon him) teaches the Kumail prayer to Kumail ibn Ziad or composes the Homam sermon, a sermon describing the faithful, for this man. All these evidences show difference in qualities and potentials among sahaba and companions of imams.

Here, we come to this conclusion that though narratives of sahaba are taken as a valid source for interpretation of the Quran but they are not the only source because in many cases sahaba might have expressed their personal opinions and comments. Surely, their statements reveal some level of knowledge of the Quran but not all that God Almighty suggests. Therefore interpreters in each age must reflect on the meaning of Quran's verses and formulate new exegesis of the Quran coming generations. Motahari says on this issue: "don't think the meaning of the Quran is the one understood by Arabs of early Islamic era. We must try to realize what they grasped from the Quran. Don't think the Quran's content is limited to what they understood. Never. The Quran has not been revealed for Arabs of that age. The Quran has 
been revealed for the entire humanity and until the Day of Resurrection no one is entitled to interpret the Quran based on personal carnal desires. However, all have the right to contemplate the Quran for ever, and have this chance to find new issues in the Quran, the matters that might have not been noticed by their ancestors." (Motahari, 1366, pp. 162)

Third reason: The improvement of human knowledge and perception in the course of history Man is distinguished from other animals by the faculty of reasoning. The man's benefit from the power of thinking and reasoning determines man's understanding of the world. No one can doubt this fact that the intellectual capacity and reasoning power of man have been different in different eras, and it is certain that human society and man's thought has been the subject of a incessant development and.

This evolution is observable in all stages of life even in interpreting the Quran. By a look at the history of Quran interpretation from the first Hegira century up to now deep developments are seen. This development may be witnessed in theology, social knowledge, history, literature and science. These changes are the product of nothing but the improvement of human beings' wisdom and the development of thinking. With no doubt the improvement of thoughts remarkably helps the better understanding of God's purpose and allows interpreters to deduce the Quran's message more efficiently.

In every epoch and age, the quality of interpretation of the Quran and understanding its implications and concepts depends on the intellect of people and the extent of science in that era. An interpretation of the Quran in an era may seem extremely simple and shallow in another age. The history of the Quran shows it has been understood much better with the passage of time similar to the improvement of man's knowledge of nature in the course of time. (Motahari, 1366, pp. 163) The deepening understanding of a fact may cause a treatise or theory becomes totally or partially invalid in the next century.

"You cannot find a scholar, both Muslim and non-Muslim, whose ideas and opinions have not become obsolete by at least eighty percent. See Avicenna. Half of his theories are outmoded today. Descartes' philosophy is also obsolete now so that his ideas are the subject of joking. Today when you look at Iddah of Shaykh Tusi and compare it with Rasail of Shaykh Ansari you come to the conclusion that the former must only be kept in museums, it is no longer worthy enough to be considered as a textbook, this is also true with Shaykh Saduq and Muhaqeq Helli. You can't find a scholar with books that always remain animated. Coming scholars make statements that abolish their previous statements." (Motahari, 1362, pp. 262)

For this reason, Imam Khomeini, in interpreting Hamd sura, says: "I may speak a few words about some verses of the Holy Quran, but I don't claim the meaning of the Quran is what I say and nothing else. I talk with some probability not certainty. I will never say the meaning is this and nothing else." (Imam Khomeini, 2002, pp. 96)

For the development of science and the refreshment of interpretations of the Quran no interpreter describes his exegesis perfect, and always accepts that their ideas may be truth or not.

Concerning the history of interpretation of the Quran and refreshment of our knowledge, an Egyptian author and researcher says: "The explicit text of the Quran was in interaction with human sciences in the course of history and acted as an inspiration for interpreters to use human culture and view and experimental science of their time in interpretation of the Quran. The more the interpreters polished their knowledge of the secrets of the existence and penetrated into the soul of human beings probing into the depth of the Quran and its features became more fruitful and deeper." (Sharqavi, 1979, p. 45)

Therefore, the interpreter's scientific information can improve interpretation and the creation of new and fresh meanings. Here, we point to examples of different interpretations of the same issue in early centuries and at present: 
In interpreting the verse "It is Allah who erected the heavens without pillars that you [can] see" (Al-Ra'd, 2) Fakhr Razi states the suspension of the sky is impossible due to its size and only a supranatural force can hold celestial objects in the sky (Fakhr Razi, 1416, vol. 23, pp. 167). However, he fails to explain how celestial objects suspend in the sky but, on the other hand, contemporary interpreters, due to their access to modern sciences, disclose the secret of the suspension of the objects in the sky without the need for a column or base. A contemporary interpreter of the Quran says: "This verse speaks of a force that holds objects in the space without the need for a base. Gravity keeps stars and celestial objects in the sky and this is not unnatural. This is a phenomenon caused by constant divine laws." (Sadeqi Tehrani, 1986, vol. $12 \& 13$, pp. 246)

This change in interpreter's view is not limited to the explanation of natural phenomena but their understanding of attributes of God Almighty has been subjected to a development. Motahari says: "for instance, consider Tawhid [doctrine of oneness] and related issues, attributes of God, positive and negative attributes, destiny, determination and will etc. Look at books of brilliant people of the last millennium, for example, Sheikh Saduq. Then look at the contemporary works, when the science of Tawhid and has progressed considerably. You will see how childish are Sheikh Saduq's interpretations and justifications as compared to mature Tawhid science. One is surprised how this man couldn't correctly interpret verses of the Quran on Tawhid. For example, when he is discussing attributes of God, he assigns positive attributes to negative attributes. The Quran says God is omniscient, living and everlasting. Sheikh Saduq cannot even solve this problem correctly; how can God be called omniscient without injuring its majesty and divinity? Sheikh Saduq says God is omniscient means that God is not ignorant! God is omnipotent means that God is not weak! God is living means that God is not dying! In other words, he tries to explain positive attributes by means of negative attributes. Surely if we were contemporaneous with him we could not explain these matters better. Such justifications are frustrating. When our knowledge of Tawhid is improved we realize there is no need for such justifications."

\section{Analysis and discussion}

Undoubtedly, the progress of sciences has paved the way for diverse studies on interpretation of the Quran. Without these sciences we could never probe into fine truths in the Quran, and perhaps we would be subjected to incorrect interpretations of the Quran. Here, it is found that the validity of holy verses of the Quran is not limited to a certain age but they are well-grounded for all times. Therefore, the Holy Quran should be studied with respect to development of the same period and new concepts should be extracted from it without damaging its essence and main objectives. Sciences and knowledge serve as tools for interpreters to unfold the meaning hidden in the depth of words. Meanwhile, we should avoid going to extremes to prevent distortion of the Quran and attribution of false interpretations to the Quran.

Based on what stated above, this question is raised; regarding the development of sciences and the evolution of minds and thoughts that may give rise to diverse and sometimes contradictory interpretations what will be the criterion to distinguish right interpretations from false ones?

In response to this question it may be said that the very important criterion in assessing various interpretations of the Quran is the entirety of the Quran or its sacred text. The Quran is a consistent system whose components and elements explain each other and shed light on each other. In other words, as the larger number of evidences in the Quran and its implications are found in support of that special reading of the Quran that reading will be more valid and valuable, and a reading which is not supported by evidences and implications in the Quran that reading will be invalid and inappropriate. 
Therefore, the extensibility of the meaning of the Quran's words should be in accordance certain conditions and criteria without which the extending the scope and meaning of the words will not be acceptable.

\section{Fourth reason; The tradition of the Fourteen Infallibles (peace be upon them) in semantic extensibility}

The narratives left from the Fourteen Infallibles are not of the same type and category but they can be divided into various classes. Some divide the narratives into tafsir and tawil. Some describe these methods as the "interpretation of appearance" and the "interpretation of essence". Some other categorize interpretative narratives into the narratives of meaning and narratives of instances (Shaker, 2003, pp. 307)

Here, we point to some narratives describing instances:

"Indeed, the righteous will be in pleasure, and indeed, the wicked will be in Hellfire." (Al-Infitar, 13 \& 14)

Imam Baqir (peace be upon him) is quoted as saying "we are the beneficent and our enemies are the evil." (Zarkeshi, 1415, vol. 4, pp. 436)

Another instance is about the word suht. Imam Sadiq (peace be upon him) is quoted as saying: "Imam Ali (peace be upon him) said suht means the money paid for a dead animal and dog and the money paid to a prostitute, a bribe given to a judge or a kohen [Jewish cleric] are instances of suht." (Majlesi, 1403, vol. 103, pp. 42)

Allameh Tabatabaei makes a distinction between instances and jary. He defines jary as the accordance between the instances that have emerged in the course of time. Allameh Tabataei uses the term instance concerning narratives to refer to the instances that existed at the time of revelation.

Other narratives left from the Fourteen Infallibles (peace be upon them) are those that refer to the essence or heart of the verses. Recent scholars use tawil to the interpretations of the Quran that have no explicit relation with the immediate meaning of words and phrases. Therefore, tawil may be described as returning speech from the apparent meaning to a meaning for which there is not equivalence in the language.

Of course there may be some degree of the meaning explored by tawil and the apparent meaning of the world but this correspondence does not follow a definite rule that can be learned by all who intend to interpret the Quran (Ma'aref, 2004, pp. 242). As an example, look at the interpretation of the verse Say, "Have you considered: if your water was to become sunken [into the earth], then who could bring you flowing water?" where water is interpreted as Imam and Sunken as the Occlusion of Imam (Al-Ghayba) (Hoveyzi, 2003, vol. 5, pp. 387). The third class of narratives left from imams (peace be upon them) are the narratives extending the semantic scope of words. It seems imams (peace be upon them) attributed special meanings to certain words for which those meaning were unprecedented. An example of this semantic technique is seen in the famous hadith from the Prophet of Islam (may God's peace be upon him) on characterizing momen [believer], Muslim and muhajer [emigrant]. In this hadith, Imam Baqir (peace be upon him) quotes the Prophet as saying: "do you like to be informed of the meaning momen? Momen is the one whom is trusted by other believers in entrusting hi their properties and lives. Do you like to be informed of the meaning of Muslim? Muslim is the one who does not hurt other Muslims by his act or speech. And about the meaning of muhajer! Muhajer is the one who avoid evil acts and gives up what has been prohibited by God Almighty." (Majlesi, 1403, vol. 64, pp. 358)

This approach towards the meaning of muhajer is interesting because the Quran describes hirat [emigration, reference to the emigration of Muslims from Mecca to Medina to escape prosecution of non-Muslims] as a religious value and advantage but the Prophet interpret this word to mean refrain from evil acts. 
Similarly, while some philologists tell rejs means evil and vicious this word in the Prophet's speech refers to plagues and sins, and in another hadith quoted by Zararah and Abu Basir this world is used in the meaning of doubt (Sheikh Saduq, 1399, pp. 138).

These are only few instances of the interpretation of the Quran by imams (peace be upon them) a in an extensive manner and we can present numerous examples in this area (see Majlesi, ibid)

\section{Analysis and discussion}

One of the important sources in interpreting the Holy Quran are the reliable narratives on the interpretation of the Quran by imams. Identifying and classifying these narratives, especially interpretative narratives related to Imam Ali, is an important task of an interpreter. In this connection, paying heed to the narratives on the interpretation of the Quran left from Imam Ali that have played a significant role in polishing the Shiite's school of interpretation is of high importance. Contemplation of these narratives shows that Imam Ali was not satisfied with the interpretation of the apparent meaning of verses but he carried out a rational interpretation of them. This technique was later used by Shia and Mutazali. (Dehghan Mangabadi, 2004, pp. $50)$.

Religious scripts have emphasized the need for attending various meanings of words that lead to different meaning of speeches and equates this qualification with highest rank in jurisprudential knowledge of the researcher. Davud bin Faraghd quotes Imam Sadiq as saying: "you will be the most conscious men when you understand the meaning of our speeches. Each word may be attributed various meaning, and man can willfully distort the meanings without telling a lie." (Sheikh Saduq, 1399, p. 1)

On the other hand, a considerable amount of comparative narratives suffer from extreme weaknesses in terms of evidence and document. Surely, these false narratives are fabricated by liars and enemies of the Ahl Al-Bayt (peace be upon them) [the family of the Prophet of Islam]. It is of high importance to distinguish these narratives that is beyond the scope of this writing. In comparative Quran studies we should be careful not to be manipulated by Ghulat [some Muslim minorities who ascribe divine characteristics figures to figures, mostly Shiite imams] and enemies and should not let their comparative method pervert us. Holy imams (peace be upon them) strongly opposed these deviated cults and never approved them. (Ma'aref and Oujaghloo, 2006, pp. 157)

In the present time, conscious Quran interpreters who seek to present up-to-date exegeses to meet current needs must adopt the same approach of imams (peace be upon them) and precisely extend semantic potentials of the meanings of Quran's words.

\section{Conclusion}

Regarding the need for using the Quran, as the last and perfect divine book, in all stages of human life and with respect to its various miraculous aspects and also because of different doubts raised by opponents of Islam and the need for responding to these fault-finding, the Quran interpreters and Islamic theologians should try to use all lexical and semantic capacities of the Quran. Extensibility of the meaning of the Quran's words does not mean transforming the connotation of words but extending and elaborating the meanings by using modern sciences and with respect to everyday needs of human beings. In other words, the new extended meanings not only are in contrast with general purposes of the Quran but help the enhancement of our knowledge of the Quran and its goals. Many Quran interpreters, both past and contemporary ones, have abided by this method and have discussed their reasons in support of it. The most important arguments in favor of this method were summarized as follows: the Holy Quran is the product of the God Almighty, therefore it has the potential of being polysemic, furthermore different perceptive faculty of people at the time of revelation and in next generations encourages various understandings, and also the growing intellectual capacity 
of men in the course of history can pave the way for the presentation of new interpretations of the Quran, and finally the Fourteen Infallibles (peace be upon them) have favored extending the meaning and scope of the Quran's words. Though each of these reasons by itself may not be persuasive but they altogether can support this method.

In reviewing opponents and proponents of this method we may note other reasons. For instance, limiting the meaning of the Quran's words to the knowledge of the people of the revelation era cause overlooking many lofty messages of the Quran because the primitive and naïve understanding of the people of the time of revelation entangles excellent meanings of the Quran in time and location limits and prevents the full use of semantic potentials of the Quran. Additionally, adopting this strict method means denying the Quran as a miracle and masterpiece of eloquence and significance, which is not discernible by non-Arab speaking people, while the Quran itself frequently states its wonders will never end. Surely, this assertion refers to the vast meanings of words in the Quran that had a very strict and limited scope in the age of sahaba but today have expanded due to the light of science and faith. 


\section{Acknowledgement}

Friends who have helped me in writing this paper am grateful, as well as the parents.

\section{References}

- The Holy Quran, translated by Mehdi Fooladvand

- Ibn Ashur, Mohammadtaher, 1884, Al-Tahrir and Al-Tanvir, vol. 1, Tunisia, Dar Al-Tunisiyeh

- As'adi, Mohammad, 2007, Semantic Shades and Layers, Qom, Bustan Ketab

- Ibn Khaldun, Abdulrahman bin Muhammad, 1996, Muqaddimah, translated by Mohammad Parvin Gonabadi, Tehran, Elmi Farhangi Publication

- Ibn Kasir, Abulfada Ismaeil bin Amro, 1412, Tafsir Al-Quran Al-Azim, vol. 2, Beirut, Dar Al-Marafa

- Ayazi, Mohamamdali, 2007, Inclusivity of Meaning in the Holy Quran, Collection of Articles in Commemoration of Ayatollah Mirza Ali Falsafi, Qom, Imam Reza Ma'aref Eslami Institute

- Balaghi, Mohammadjavad, Al-Rahman fi Tafsir Al-Quran, Beirut, Dar Al-Ahya Taras Al-Arabi

- Javadi Amoli, Abdollah, 1999, Tafsir-e Tasnim, Qom, Asra Publication Center

- Hoveyzi, Abd Ali bin Juma, 2003, Noor Al-Seghlayn, edited by Seyed Hashem Rasuli Mahallati, Qom, Al-Hekma Publication House

- Khomeini, Ruhollah, 2002, Interpretation of Al-Hamd Sura, Tehran, Institute for Compiling and Publishing Imam Khomeini's Writings

- Dehgan Mangabadi, Bemanali, 2004, The Role of Imam Ali and the Caliphs Preceding him in Quran Interpretation, Humanities International Journal, period 11, No. 2, pp. 41-53)

- Rajabi, Mahmoud, et al., 2008, Methodology of the Quran Interpretation, Qom, Seminary and University Unity Research Center

- Zarkeshi, Badreddin, 1414, Al-Bahr Al-Muhit, Research Committee of Al-Azhar Scholars, Dar Al-Kotob

- Sajjadi, Ebrahim, 2000, Interpretation from Views and Thoughts, Quran Research Quarterly, No. $21 \& 22$

- Sivati, Jalaleddin, 1986, Al-Dor Al-Mansur, vol. 6, Jeddah, Dar Al-Marafa

- Shatebi, Ibrahim bin Musa, 1415, Al-Mavafeghat fi Osul Al-Sharia, research by Ibrahim Ramadan, Beirut, Dar Al-Marafa

- Shaker, Mohammadkazem, 1997, Methods of Quran Interpretation, Qom, Islamic Extension Office

- Al-Sharqavi, Effat Muhammad, 1979, Religious Thought in Confrontation with Time, Beirut, Dar Al-Owda, Sani Publication

- Sadeqi Tehran, Mohammad, 1986, Al-Furqan fi Tafsir Quran, Qom, Islamic Culture Publication House

- Saduq, Muhammad bin Ali, 1399, Ma'ani Al-Akhbar, edited by Aliakbar Ghafari, Beirut, Dar Al-Marafa Institute

- Tabari, Muhammad bin Jarir, 1420, Jame Al-Bayan fi Tawil Al-Quran, Beirut, Dar Al-Kotob Elmiyah

- Tayeb Hosseini, Seyed Mahmoud, 2009, Polysemy in Holy Quran, Qom, Seminary and University Unity Research Center

- Fakhr Razi, Muhammad bin Amro, 1416, Mafatih Al-Ghayb, Beirut, Dar Al-Ahya Al-taras Al-Arabi

- Kolayni, Muhammad bin Yaqub, Al-Kafi, edited by Aliakbar Ghafari, Tehran, Dar Al-Kotob Islamiyah 
- Kamali Dezfuli, Seyed Ali, 1985, Introduction to the Quran, Fajr Publication House

- Majlesi, Mohammadbaqer, 1403, Bahar Al-Anvar, Beirut, Dar Al-Ahya Al-taras Al-Arabi

- Motahari, Morteza, 1983, Islam and Requirements of the Time, Tehran, Sadra Publication House

- Maaref, Majid, 2004, Topics in History and Sciences of the Quran, Naba Publication House 